\title{
Purification and characterization of a novel laccase from the mushroom Pleurotus nebrodensis
}

\author{
Guo-Ting Tian¹, Guo-Qing Zhang², He-Xiang Wang ${ }^{3 凶}$ and Tzi Bun Ng ${ }^{4 \bowtie}$ \\ IInstitute of Biotechnology and Germplasmic Resource, Yunnan Academy of Agricultural Science, Kunming, China; 2Key Laboratory of Urban \\ Agriculture (North) of Ministry of Agriculture, Beijing University of Agriculture, Beijing, China; ${ }^{3}$ State Key Laboratory for Agrobiotechnology and \\ Department of Microbiology, China Agricultural University, Beijing, China; ${ }^{4}$ Department of Biochemistry, Faculty of Medicine, The Chinese Uni- \\ versity of Hong Kong, Shatin, New Territories, Hong Kong, China
}

\begin{abstract}
A novel laccase with a molecular mass of $64 \mathrm{kDa}$ and the N-terminal sequence AIGPDDTINF was isolated from fresh fruiting bodies of the mushroom Pleurotus nebrodensis. The purification protocol comprised ion exchange chromatography on DEAE-cellulose, CM-cellulose, and Q-Sepharose, and gel filtration on Superdex 75. The laccase was adsorbed on DEAE-cellulose and QSepharose, but not on CM-cellulose. It demonstrated an optimal temperature of $70^{\circ} \mathrm{C}$. The enzyme activity increased steadily over the temperature range $20^{\circ} \mathrm{C}-70^{\circ} \mathrm{C}$. There was only a slight reduction in activity at $80^{\circ} \mathrm{C}$. However, all activity disappeared following exposure to $100^{\circ} \mathrm{C}$ for 10 minutes. The enzyme activity changed only slightly over the $\mathrm{pH}$ range $3-5$, with the optimum at $\mathrm{pH}$ 5 , but underwent a precipitous decline when the $\mathrm{pH}$ was elevated to 6 , and was undetectable at $\mathrm{pH} 8$ and $\mathrm{pH} 9$.
\end{abstract}

Key words: Laccase, Pleurotus nebrodensis, purification, characterization

Received: 10 April, 2012; revised: 03 July, 2012; accepted: 24 August, 2012; available on-line: 03 September, 2012

\section{INTRODUCTION}

Laccase (E.C.1.10.3.2, benzenediol:oxygen oxidoreductase) is a copper-protein belonging to the group of blue oxidases (Baldrian, 2006). Laccase catalyzes the oxidation of various phenolic compounds and aromatic amines with molecular oxygen as the electron acceptor (Palmieri et al., 1993). It is widely distributed among plants, insects, bacteria, and fungi, and laccase from fungi, especially from white rot fungi, plays an important role in the natural degradation of lignin (Baldrian, 2006). Fungal laccases demonstrate great applications in biodegradation of lignin, and recently they have also found potential applications in wood pulping, manufacturing of textile dyes, detoxification of polluted water, and as biosensors (Widsten \& Kandelbauer, 2008).

Mushrooms have drawn attention of investigators since they constitute a source of important compounds comprising lectins, laccases, proteases, ribonucleases, ribosome inactivating proteins, antibacterial proteins, antifungal proteins, and polysaccharides (Ng, 2004). Many of them belong to white rot fungi, and a number of mushroom laccases have been reported in the literature (Hu et al., 2011; Li et al., 2010; Wang \& Ng, 2006a). To date, there are only several publications on Pleurotus nebrodensis, most of which are on classification of the mushroom and the taxonomic relationship between $P$. nebrodensis and P. eryngii (Urbanelli et al., 2007; Zhang et al., 2006). One study showed that the mushroom is abundant in vitamin B12 and riboflavin, and has a low caloric content and a high gastronomic value (La Guardia et al., 2005). Only one protein, a hemolysin, has been isolated from $P$. nebrodensis ( $\mathrm{Lv}$ et al., 2009). In view of the importance of laccases, the present study aimed to isolate and characterize a laccase from the mushroom $P$. nebrodensis, and to compare its characteristics with those of other laccases from the genus Pleurotus.

\section{MATERIALS AND METHODS}

Isolation of laccase. Fresh fruiting bodies (1500 g) of the mushroom P. nebrodensis were homogenized in distilled water $(4500 \mathrm{ml})$ using a Waring blender. The homogenate was centrifuged at $12000 \mathrm{rpm}$ for 15 minutes. Tris/HCl buffer ( $1 \mathrm{M}, \mathrm{pH}$ 7.4) was added to the resulting supernatant to a final concentration of $10 \mathrm{mM}$. The supernatant was then loaded on $5 \mathrm{~cm} \times 20 \mathrm{~cm}$ columns of DEAE-cellulose (Sigma, USA) in $10 \mathrm{mM}$ Tris $/ \mathrm{HCl}$ buffer ( $\mathrm{pH}$ 7.4). Unadsorbed proteins were collected in the flowthrough fraction, and adsorbed proteins were eluted with the same buffer containing $0.8 \mathrm{M} \mathrm{NaCl}$. Enzyme fraction was further purified on $2.5 \mathrm{~cm} \times 20$ $\mathrm{cm}$ columns of CM-cellulose (Sigma, USA) in $10 \mathrm{mM}$ $\mathrm{NH}_{4} \mathrm{OAc}$ buffer ( $\mathrm{pH}$ 4.5). After elution of unadsorbed proteins, the same $\mathrm{NH}_{4} \mathrm{OAc}$ buffer with $1 \mathrm{M} \mathrm{NaCl}$ was used for adsorbed ones. Subsequently, the active fraction was chromatographied on a $2.5 \mathrm{~cm} \times 20 \mathrm{~cm}$ column of Q-Sepharose (GE Healthcare, USA). Following elution of unadsorbed proteins with $10 \mathrm{mM}$ Tris/ $\mathrm{HCl}$ buffer $(\mathrm{pH}$ 7.4), the adsorbed proteins were eluted with a linear concentration gradient of $\mathrm{NaCl}(0-1 \mathrm{M})$ in the same Tris/HCl buffer. Finally, the laccase fraction was dialyzed, lyophilized, and then chromatographied on a Superdex $75 \mathrm{HR}$ 10/30 column (GE Healthcare) in $0.2 \mathrm{M}$ $\mathrm{NH}_{4} \mathrm{HCO}_{3}$ buffer ( $\mathrm{pH}$ 8.5) using an AKTA Purifier (GE Healthcare, USA).

Assay of laccase activity. Laccase activity was assayed by measuring the oxidation of $2,7^{\prime}$-azinobis [3-ethylbenzothiazolone-6-sulfonic acid] diammonium salt (ABTS). A modification of the method of Shin and Lee

e-mail: H.X. Wang — hxwang@cau.edu.cn TB Ng - b021770@mailserv.cuhk.edu.hk

Abbreviations: DEAE, Diethylaminoethyl; CM, carboxymethyl OSepharose, quaternary amine sepharose; FPLC, fast protein liquid chromatography; SDS-PAGE, sodium dodecyl sulfatepolyacrylamide gel electrophoresis; HPLC, high performance liquid chromatography; ABTS, 2, 7'-azinobis [3-ethylbenzothiazolone-6-sulfonic acid] diammonium salt; HIV-1, human immunodeficiency virus type 1 


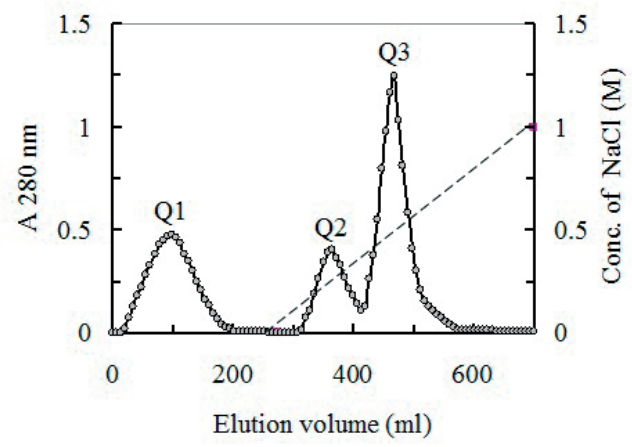

Figure 1. lon exchange chromatography on Q-Sepharose.

Sample: $P$. nebrodensis fruiting body extract adsorbed on DEAEcellulose and then unadsorbed on CM-cellulose. Column dimensions: $2.5 \times 20 \mathrm{~cm}$. Starting buffer for eluting fraction Q1 $10 \mathrm{mM}$ Tris/ $\mathrm{HCl}$ ( $\mathrm{pH}$ 7.4). Buffer for eluting fractions Q2 and Q3: 0-1 M $\mathrm{NaCl}$ gradient in starting buffer.

(2000) was used. An aliquot of enzyme solution was incubated in $1.3 \mathrm{ml}$ of $67 \mathrm{mM}$ sodium acetate buffer $(\mathrm{pH}$ 4.5) containing $1.54 \mathrm{mM}$ ABTS at $30^{\circ} \mathrm{C}$. One unit of enzyme activity was defined as the amount of enzyme required to produce an absorbance increase at $405 \mathrm{~nm}$ of one per min per $\mathrm{ml}$ of reaction mixture under the aforementioned condition (Zhang et al., 2011).

Molecular mass determination by sodium dodecyl sulfate polyacrylamide gel electrophoresis (SDS/ PAGE) and by FPLC gel filtration. SDS/PAGE was carried out in accordance with the procedure of Laemmli and Favre (1973), using a 12\% resolving gel and a 5\% stacking gel. At the end of electrophoresis, the gel was stained with Coomassie brilliant blue. FPLC gel filtration was carried out using a Superdex 75 HR 10/30 column which had been calibrated with molecular mass standards (GE Healthcare, USA).

Analysis of $\mathrm{N}$-terminal amino acid sequence. $\mathrm{N}$-terminal amino acid sequence analysis was carried out using an HP G1000A Edman degradation unit and an HP1000 HPLC system (Zhang et al., 2011).

Substrate specificity of isolated laccase. To determine the substrate specificity of the purified laccase, several aromatic substrates were added to the assay media in place of ABTS. The substrates used $(5.0 \mathrm{mM})$ were ABTS, N,N-dimethyl-1,4-phenylenediamine, catechol, hydroquinone, 2-methylcatechol, pyrogallol, and tyrosine.
The enzyme assay was performed as described above and the test buffer was sodium acetate buffer ( $\mathrm{pH} 4.5$ ). The substrate oxidation rate was followed by measuring the absorbance change with the molar extinction coefficients $(\varepsilon)$ obtained from the literature (Eggert et al., 1996; Galhaup et al., 2002).

Assay for temperature and $\mathrm{pH}$ optima. To determine the optimal temperature, the standard laccase activity assay was ran at 20, 25, 30, 40, 50, 60, 70, 80, and $100^{\circ} \mathrm{C}$. The assay buffer was the same sodium acetate buffer used in the standard assay described above. In the assay for optimal $\mathrm{pH}$ value, enzyme activities were determined using the standard laccase assay above, but in a series of assay buffers in a $\mathrm{pH}$ range of 3.0-9.0 instead of the sodium acetate buffer $(\mathrm{pH} 4.5)$. The assay buffers were $50 \mathrm{mM} \mathrm{NaOAc-HAc}$ ( $\mathrm{pH} 3.0-5.0)$, Mes (pH 5.0-7.0), and Hepes (pH 7.0-9.0).

Assay for bioactivities. HIV-1 reverse transcriptase inhibitory activity was carried out using an assay kit from Boehringer Mannhein (Germany) (Zhao et al., 2009). Antiproliferative activity towards tumor cell lines including human breast cancer (MCF-7) and hepatoma (HepG2) was assayed using a standard method described by Lam and $\mathrm{Ng}$ (2001). Antifungal activity towards Fusarium oxysporum, Rhizoctonia cerealis, Rhizoctonia solani, and Sclerotinia sclerotiorum was carried out using Li's method (Li et al., 2011).

\section{RESULTS AND DISCUSSION}

Purification of laccase. The fraction of P. nebrodensis fruiting body extract that was adsorbed on DEAEcellulose (fraction D2) and subsequently unadsorbed on CM-cellulose (fraction C1) contained the bulk of laccase activity (Table 1). Ion exchange chromatography of fraction $\mathrm{C} 1$ on Q-Sepharose yielded an unadsorbed peak (fraction Q1), a small adsorbed peak (fraction Q2) and a large adsorbed peak (fraction Q3) (Fig. 1). Laccase activity resided in fraction Q2 (Table 1). Q2 was resolved on Superdex 75 into two peaks of similar size (Fig. 2). Laccase activity was enriched in the first peak SU1 (Table 1). In brief, the laccase resided in adsorbed fraction D2 of DEAE-cellulose, then unadsorbed fraction C1, then adsorbed fraction Q2 of Q-Sepharose, and finally fraction SU1 of FPLC.

Most of the laccases reported in the literature were isolated from mycelia and not from fruiting bodies of mushroom. It is known that straw mushroom myce-

Table 1. Yield and laccase activities of various chromatographic fractions (from $1.5 \mathrm{~kg}$ fresh fruiting bodies, $30^{\circ} \mathrm{C}$ )

\begin{tabular}{|c|c|c|c|c|c|}
\hline Fraction & $\begin{array}{l}\text { Protein } \\
\text { (mg) }\end{array}$ & $\begin{array}{l}\text { Laccase activity } \\
\text { (u/mg) }\end{array}$ & $\begin{array}{l}\text { Total activity } \\
\text { (u) }\end{array}$ & $\begin{array}{l}\text { Yield } \\
(\%)\end{array}$ & $\begin{array}{l}\text { Purification } \\
\text { fold }\end{array}$ \\
\hline Extract & 3810 & 3.0 & 11430 & 100 & 1 \\
\hline D1 & 1163 & $<0.1$ & & & - \\
\hline D2 & 1312 & 5.9 & 7741 & 68 & 2 \\
\hline CM1 & 547 & 9.2 & 5032 & 44 & 3 \\
\hline $\mathrm{CM} 2$ & 396 & 1.8 & & & - \\
\hline Q1 & 15 & $<0.1$ & & & - \\
\hline Q2 & 64 & 45.2 & 2893 & 25 & 15 \\
\hline Q3 & 165 & 2.0 & & & - \\
\hline SU1 (Purified laccase) & 18.3 & 92.5 & 1693 & 15 & 31 \\
\hline SU2 & 21.4 & 2.1 & & & - \\
\hline
\end{tabular}

Data corresponding to the most active fraction at each chromotographic step are shown in boldface. 


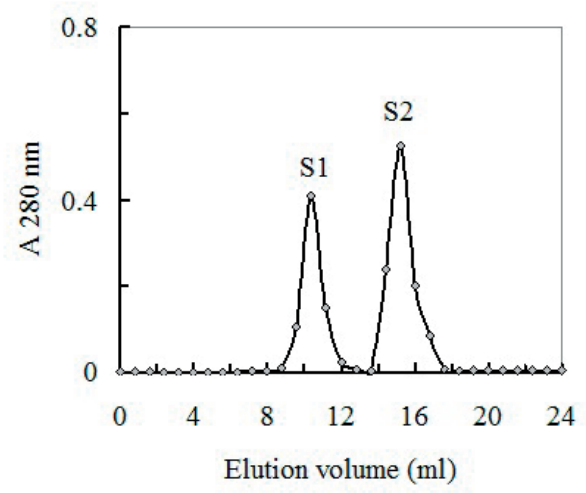

Figure 2. Gel filtration by fast protein liquid chromatography on a Superdex 75 HR 10/30 column using an AKTA Purifier System (GE Healthcare, USA).

Sample: fraction Q2. Eluent: $0.2 \mathrm{M} \mathrm{NH}_{4} \mathrm{HCO}_{3}(\mathrm{pH}$ 8.5). Flow rate: 0.4 $\mathrm{ml} / \mathrm{min}$. Fraction size: $0.8 \mathrm{ml}$

lia and fruiting bodies elaborate the same lectin (She et al., 1998). However, dissimilar lectins are extracted from Tricholoma mongolicum mycelia (Wang et al., 1996) and fruiting bodies (Wang et al., 1998). It is reported herein that a laccase can be purified from the fruiting bodies of the mushroom $P$. nebrodensis. The procedure employed in the present study was useful for isolating Pleurotus nebrodensis laccase. Proteins with little or no laccase activity were separated from the laccase-enriched fraction in each of the chromatographic steps on DEAE-cellulose, CM-cellulose, Q-Sepharose and Superdex 75. In contrast to some of the previously reported laccases, e.g., those from Coriolus birsutus (Shin \& Lee, 2000) and Rigidoporus lignosus (Cambria et al., 2000), which are adsorbed on
$\mathrm{kDa}$ marker laccase

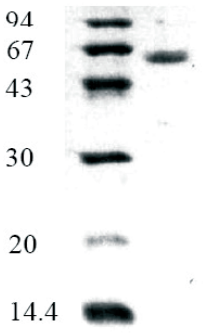

Figure 3. Sodium dodecyl sulfate-polyacrylamide gel electrophoresis.

Left lane: Molecular mass standards (GE Healthcare, USA). From top downward: phosphorylase b $(94 \mathrm{kDa})$, bovine serum albumin $(67 \mathrm{kDa})$, ovalbumin $(43 \mathrm{kDa})$, carbonic anhydrase (30 kDa), soybean trypsin inhibitor $(20 \mathrm{kDa})$ and $\alpha$-lactalbumin (14.4 kDa). Right lane: $P$. nebrodensis laccase.

cationic and anionic exchangers including DEAE-Sepharose, Q-Sepharose and Hitrap-SP, the P. nebrodensis laccase is adsorbed on DEAE-cellulose and Q-Sepharose but unadsorbed on CM-cellulose.

Molecular mass determination and N-terminal sequence analysis. SU1 appeared as a single band with a molecular mass of $64 \mathrm{kDa}$ in SDS-PAGE (Fig. 3) and a single peak with the same molecular mass upon rechromatography on a Superdex 75 column (data not shown). It represented purified laccase. The $\mathrm{N}$-terminal sequence of $P$. nebrodensis laccase showed only little similarity to other mushroom laccases (Table 2). Its molecular mass lies within the range of molecular masses found for mushroom laccases (Baldrian, 2006). Its N-terminal sequence does not, however, resemble previously isolated mushroom laccases to any great extent.

Table 2. $\mathrm{N}$-terminal sequence comparison of laccases from $P$. nebrodensis and other mushrooms

\begin{tabular}{|c|c|c|}
\hline Mushroom laccase & $\mathrm{N}$-terminal sequence & Ref. \\
\hline Pleurotus nebrodensis laccase & AIGPDDTINF & This study \\
\hline Pleurotus eryngii laccase I (fruiting body ) & $\underline{A V G P V L G P D A}$ & (Wang \& Ng, 2006b) \\
\hline Pleurotus eryngii laccase I ( mycelial) & $\underline{A}$ XKKLDFFHII & (Munoz et al., 1997) \\
\hline Pleurotus eryngii laccase II (mycelial) & $\underline{\text { ATKKLDFHII }}$ & (Munoz et al., 1997) \\
\hline Agaricus bisporus I & KTRTFDFDLV & (Perry et al., 1993) \\
\hline Agaricus bisporus laccase II & DTKTFNFDLV & (Perry et al., 1993) \\
\hline Albatrella dispansus laccase & AQPPNYHYN & (Wang \& Ng, 2004b) \\
\hline Basidiomycete PM1 laccase & SIGPVADLTI & (Coll et al., 1993) \\
\hline Cantherellus cibarius laccase & GCCNCGHA & (Ng \& Wang, 2004) \\
\hline Ceriporiopsis subvermispora laccase & AIGPVTDLEI & (Fukushima \& Kirk, 1995) \\
\hline Coriolus hirsutus laccase & AIGPTADLTI & (Kojima et al., 1990) \\
\hline Coriolus hirsutus laccase & GIGTKANLVI & (Shin \& Lee, 2000) \\
\hline Ganoderma lucidum laccase & GQNGDAVP & (Wang et al., 2006a) \\
\hline Hericium erinaceum laccase & AVDDDAEQIP & (Wang \& Ng, 2004a) \\
\hline Phlebia radiata laccase & SIGPVTDFHI & (Saloheimo et al., 1991) \\
\hline Pycnoporus cinnabarinus laccase & AIGPVADLTI & (Eggert et al., 1996) \\
\hline Trametes versicolor laccase I & AIGPVASLVV & (Bourbonnais et al., 1995) \\
\hline Trametes versicolor laccase II & GIGPVADLTI & (Bourbonnais et al., 1995) \\
\hline Trametes versicolor laccase III & GIGPVADLTD & (Shin \& Lee, 2000) \\
\hline Tricholoma giganteum laccase & DDPQQAVIDD & (Wang \& Ng, 2004c) \\
\hline
\end{tabular}

Amino acid residues identical to corresponding residues of $P$. nebrodensis laccase are underlined. 


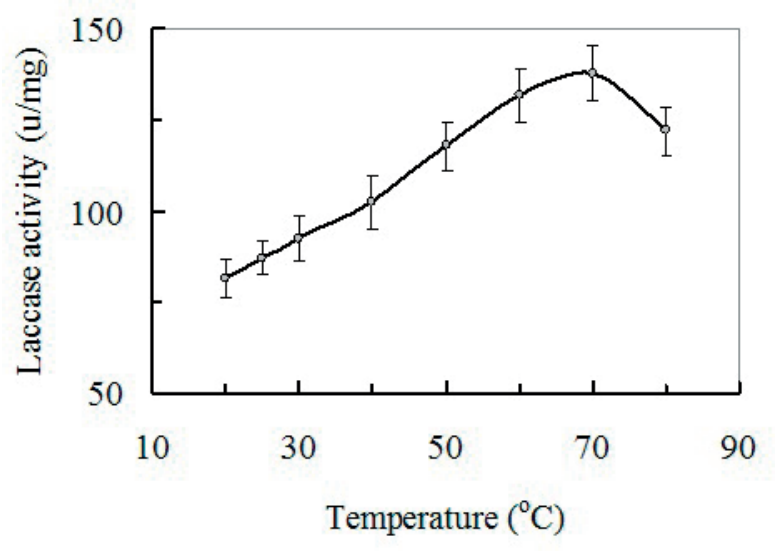

Figure 4. Dependence of $P$. nebrodensis laccase activity on temperature.

Table 3. Activities of Pleurotus nebrodensis laccase assessed against various substrates

\begin{tabular}{lll}
\hline Substrate & $\begin{array}{l}\text { Wavelength } \\
(\mathrm{nm})\end{array}$ & $\begin{array}{l}\text { Relative activity } \\
(\%)\end{array}$ \\
\hline ABTS & 420 & 100.0 \\
$\begin{array}{l}\text { N, N-Dimethyl-1,4-phenyl- } \\
\text { enediamine }\end{array}$ & 515 & 72.1 \\
Catechol & 450 & 26.7 \\
Hydroquinone & 248 & 18.2 \\
2-Methylcatechol & 436 & 13.5 \\
Pyrogallol & 450 & 7.3 \\
Tyrosine & 280 & 0.0 \\
\hline
\end{tabular}

Substrate specificity of isolated laccase. The enzyme oxidized a range of substrates, including polyphenolic substrates (hydroquinone, pyrogallol, catechol), methoxy-substituted phenols (2-methylcatechol), aromatic diamines (N,N-dimethyl-1,4-phenylenediamine) and the non-phenolic heterocyclic compound ABTS (Baldrian, 2006). The highest activity was demonstrated toward ABTS, about $70 \%$ as much activity toward N, N-dimethyl-1,4-phenylenediamine, about $25 \%$ toward catechol, more than 10\% toward hydroquinone and 2-methylcatechol, very little activity $(\sim 7 \%)$ toward pyrogallol, and no activity toward tyrosine (Table 3).

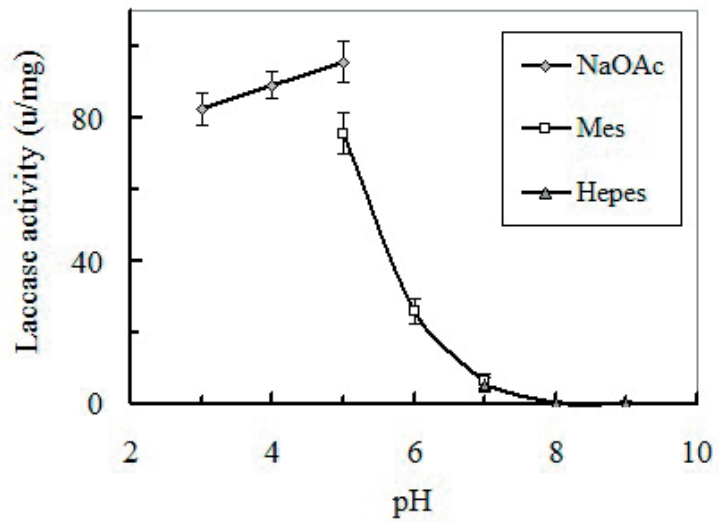

Figure 5. Dependence of $P$. nebrodensis laccase activity on $\mathrm{pH}$.

Temperature and $\mathrm{pH}$ dependence of laccase activity. The activity of the enzyme rose steadily when the temperature was raised from $20^{\circ} \mathrm{C}$ to $70^{\circ} \mathrm{C}$. The activity dropped slightly when the temperature was further raised to $80^{\circ} \mathrm{C}$ (Fig. 4). Incubation of the enzyme at $100^{\circ} \mathrm{C}$ for 10 minutes brought about complete abolition of activity. The enzyme activity increased slowly when the $\mathrm{pH}$ was elevated from 3 to 5 . A further rise in $\mathrm{pH}$ to 6 led to an abrupt drop in activity. Negligible laccase activity was detected at $\mathrm{pH} 7$ while no activity was discerned at $\mathrm{pH}$ 8 and 9 (Fig. 5).

The $P$. nebrodensis laccase is unique in that its enzymatic activity undergoes a steady increase as the temperature is raised from $20^{\circ} \mathrm{C}$ to $70^{\circ} \mathrm{C}$ and that only a small decrement in activity ensues when the temperature is further elevated to $80^{\circ} \mathrm{C}$. In contrast, $R$. lignosus laccase exhibits a temperature optimum at $45^{\circ} \mathrm{C}$ with only residual activity at $65^{\circ} \mathrm{C}$ (Cambria et al., 2000). However, the enzyme is denatured after treatment at $100^{\circ} \mathrm{C}$ for 10 minutes and all activity is lost. $P$. nebrodensis laccase requires a $\mathrm{pH}$ of 5 for it to manifest maximal activity. This finding is at variance with the observation of an optimum $\mathrm{pH}$ of $2-3$ from several other mushroom laccases (Shin \& Lee, 2000). It is noteworthy that a drastic decline in laccase activity results when the $\mathrm{pH}$ is elevated to 6 and that total loss of activity occurs at pH 8 and 9. Since the present laccase manifests a considerably high temperature optimum, it has good potential for industrial applications.

Assay for other biological activities. The laccase did not display antifungal activity, anti-proliferative activity on tumor cells or inhibitory activity toward HIV-1 reverse

Table 4. Comprison of biochemical characteristics and activities of $P$. nebrodensis laccase and other Pleurotus laccases

\begin{tabular}{|c|c|c|c|c|c|}
\hline & P. nebrodensis & P. ostreatus & P. pulmonarius & P. eryngii & P. florida \\
\hline Molecular mass (kDa) & 64 & 75 & 46 & 34 & 77 \\
\hline \multicolumn{6}{|l|}{ Chromatographic behavior on } \\
\hline DEAE-ion exchange & Adsorbed & Adsorbed & Adsorbed & Adsorbed & Adsorbed \\
\hline (ii) Q- ion exchange & Adsorbed & Adsorbed & - & Adsorbed & - \\
\hline (iii) CM- ion exchange & Unadsorbed & - & - & Unadsorbed & - \\
\hline Optimum pH & 5 & Alkaline range & $4.0-5.5$ & $3-5$ & - \\
\hline Optimum temperature & $70^{\circ} \mathrm{C}$ & $50^{\circ} \mathrm{C}$ & $50^{\circ} \mathrm{C}$ & $70^{\circ} \mathrm{C}$ & - \\
\hline HIV-1 reverse transcriptase inhibitory avtivity $\left(\mathrm{IC}_{50}\right)$ & No activity & - & - & $2.2 \mu \mathrm{M}$ & - \\
\hline
\end{tabular}

- not determined or not attempted. References: P. florida laccase (Das et al., 2000); P. ostreatus laccase (Palmieri et al., 2001); P. pulmonarius laccase (De Souza \& Peralta, 2003); P. eryngii laccase (Wang \& Ng, 2006b) 
Table 5. Comprison of biochemical characteristics and activities of $P$. nebrodensis laccase and non-Pleurotus laccases

\begin{tabular}{|c|c|c|c|c|c|c|}
\hline & P. nebrodensis & G. lucidum & H. erinaceum & A. dispansus & T. giganteum & C. cibarius \\
\hline Molecular mass (kDa) & 64 & 75 & 63 & 62 & 43 & 92 \\
\hline \multicolumn{7}{|l|}{ Chromatographic behavior on } \\
\hline $\begin{array}{l}\text { (i) DEAE-ion } \\
\text { exchange }\end{array}$ & Adsorbed & Unadsorbed & Adsorbed & Unadsorbed & Unadsorbed & Unadsorbed \\
\hline (ii) Q- ion exchange & Adsorbed & - & Adsorbed & - & - & - \\
\hline (iii) CM- ion exchange & Unadsorbed & - & Unadsorbed & - & Adsorbed & - \\
\hline 4) Affi gel blue gel & - & Unadsorbed & - & Unadsorbed & Adsorbed & Unadsorbed \\
\hline 5) Con A-Sepharose & - & Adsorbed & - & Adsorbed & - & Adsorbed \\
\hline Optimum pH & 5 & $3-5$ & 5 & 4 & 4 & 4 \\
\hline Optimum temperature & $70^{\circ} \mathrm{C}$ & $70^{\circ} \mathrm{C}$ & $50^{\circ} \mathrm{C}$ & $70^{\circ} \mathrm{C}$ & $70^{\circ} \mathrm{C}$ & $50^{\circ} \mathrm{C}$ \\
\hline $\begin{array}{l}\text { HIV-1 reverse transcriptase inhibitory } \\
\text { avtivity (IC50) }\end{array}$ & No activity & $1.2 \mu \mathrm{M}$ & $9.5 \mu \mathrm{M}$ & No activity & $2.2 \mu \mathrm{M}$ & - \\
\hline
\end{tabular}

- not determined or not attempted. References: H. erinaceum laccase (Wang \& Ng, 2004a); A. dispansus laccase (Wang \& Ng, 2004b); T. giganteum laccase (Wang \& Ng, 2004c); C. cibarius laccase (Ng \& Wang, 2004); G. lucidum laccase (Wang \& Ng, $2006 \mathrm{~b}$ ).

transcriptase when tested at a concentration of $100 \mu \mathrm{M}$ (not shown). Some mushroom products, e.g., lectins (Li et al., 2008), polysaccharopeptide (Wang \& Ng, 2001), ribosome inactivating proteins ( $\mathrm{Lam} \& \mathrm{Ng}, 2001$ ) and ubiquitin-like proteins (Wang \& Ng, 2000) manifest an inhibitory activity toward HIV-1 reverse transcriptase. Laccases from G. lucidum, $H$. erinaceum and T. giganteum also inhibit this retroviral enzyme. The $P$. nebrodensis laccase is devoid of this ability. The laccase isolated in this investigation lacks anti-proliferative and antifungal activities, in contrast to the observation that some mushroom lectins, antifungal proteins and ribonucleases show anti-proliferative activity (Wang \& Ng, 2001), and mushroom antifungal proteins inhibit mycelial growth (Lam \& Ng, 2001).

Comparisons with other Pleurotus and non-Pleurotus mushroom laccases. The comparisons are shown in Table 4 and Table 5. P. nebrodensis laccase resembled $P$. eryngii laccase (Wang \& Ng, 2006b) to the greatest extent. However, the two laccases differed in molecular mass, Nterminal sequence, optimum $\mathrm{pH}$ and presence/absence of HIV-1 reverse transcriptase inhibitory activity. When compared with non-Pleurotus laccases, the $P$. nebrodensis laccase resembled only laccases from Hericium erinaceum (Wang \& $\mathrm{Ng}, 2004 \mathrm{a}$ ) and Albatrella dispansus (Wang \& Ng, 2004b) in molecular mass. It was similar to only $H$. erinaceum laccase in optimum $\mathrm{pH}$, and laccases from Ganoderma lucidum (Wang \& Ng, 2006b), A. dispansus and Tricholuma giganteum (Wang \& Ng, 2004c) in optimum temperature. Although the $P$. nebrodensis laccase resembled the $H$. erinaceum laccase in some aspects, they differed in optimum temperature and HIV-1 reverse transcriptase inhibitory activity.

\section{Acknowledgments}

This work was financially supported by National Grants of China (2010CB732202, 2012BAD14B09, and 31200070 ) and a Beijing Innovative Grant of the Modern Agricultural Technology System.

\section{Conflict of interest}

The authors declare no conflict of interes.

\section{REFERENCES}

Baldrian P (2006) Fungal laccases - occurrence and properties. FEMS Microbiol Rev 30: 215-242.
Bourbonnais R, Paice MG, Reid ID, Lanthier P, Yaguchi M (1995) Lignin oxidation by laccase isozymes from Trametes versicolor and role of the mediator 2,2'-azinobis(3-ethylbenzthiazoline-6-sulfonate) in kraft lignin depolymerization. Appl Environ Microbiol 61: 18761880.

Cambria MT, Cambria A, Ragusa S, Rizzarelli E (2000) Production, purification, and properties of an extracellular laccase from Rigidoporus lignosus. Protein Expres Purif 18: 141-147.

Coll PM, Fernandez-Abalos JM, Villanueva JR, Santamaria R, Perez P (1993) Purification and characterization of a phenoloxidase (laccase) from the lignin-degrading basidiomycete PM1 (CECT 2971). Appl Environ Microbiol 59: 2607-2613.

Das N, Chakraborty TK, Mukherjee M (2000) Purification and characterization of laccase-1 from Pleurotus florida. Folia Microbiol (Praba) 45: $447-451$

De Souza CGM, Peralta RM (2003) Purification and characterization of the main laccase produced by the white-rot fungus Pleurotus pulmonarius on wheat bran solid state medium. J Basic Microb 43: 278-286.

Eggert C, Temp U, Eriksson KE (1996) The ligninolytic system of the white rot fungus Pycnoporus cinnabarinus: purification and characterization of the laccase. Appl Environ Microbiol 62: 1151-1158.

Fukushima Y, Kirk TK (1995) Laccase component of the Ceriporiopsis subvermispora lignin-degrading system. Appl Environ Microbiol 61: 872-876.

Galhaup C, Goller S, Peterbauer CK, Strauss J, Haltrich D (2002) Characterization of the major laccase isoenzyme from Trametes $p u$ bescens and regulation of its synthesis by metal ions. Microbiology-Sgm 148: 2159-2169.

Hu DD, Zhang RY, Zhang GQ, Wang HX, Ng TB (2011) A laccase with antiproliferative activity against tumor cells from an edible mushroom, white common Agrocybe cylindracea. Phytomedicine 18: 374-379.

Kojima Y, Tsukuda Y, Kawai Y, Tsukamoto A, Sugiura J, Sakaino M, Kita Y (1990) Cloning, sequence analysis, and expression of ligninolytic phenoloxidase genes of the white-rot basidiomycete Coriolus birsutus. J Biol Chem 265: 15224-15230.

La Guardia M, Venturella G, Venturella F (2005) On the chemical composition and nutritional value of Pleurotus taxa growing on umbelliferous plants (Apiaceae) J Agr Food Chem 53: 5997-6002.

Laemmli UK, Favre M (1973) Maturation of the head of bacteriophage T4. I. DNA packaging events. J Mol Biol 80: 575-599.

Lam SK, Ng TB (2001) Hypsin, a novel thermostable ribosome-inactivating protein with antifungal and antiproliferative activities from fruiting bodies of the edible mushroom Hypsizigus marmoreus. Biochem Biophys Res Commun 285: 1071-1075.

Li M, Wang H, Ng TB (2011) An antifungal peptide with antiproliferative activity toward tumor cells from red kidney beans. Protein Pept Lett 18: 594-600.

Li M, Zhang G, Wang H, Ng T (2010) Purification and characterization of a laccase from the edible wild mushroom Tricholoma mongolicum. J Microbiol Biotechnol 20: 1069-1076.

Li YR, Liu QH, Wang HX, Ng TB (2008) A novel lectin with potent antitumor, mitogenic and HIV-1 reverse transcriptase inhibitory activities from the edible mushroom Pleurotus citrinopileatus. Biochim Biophys Acta 1780: 51-57.

Lv H, Kong Y, Yao Q, Zhang B, Leng FW, Bian HJ, Balzarini J, Van Damme E, Bao JK (2009) Nebrodeolysin, a novel hemolytic protein 
from mushroom Pleurotus nebrodensis with apoptosis-inducing and anti-HIV-1 effects. Phytomedicine, 16: 198-205.

Munoz C, Guillen F, Martinez AT, Martinez MJ (1997) Laccase isoenzymes of Pleurotus eryngiz: characterization, catalytic properties, and participation in activation of molecular oxygen and $\mathrm{Mn} 2+$ oxidation. Appl Environ Microbiol 63: 2166-2174.

$\mathrm{Ng}$ TB (2004) Peptides and proteins from fungi. Peptides, 25: 10551073.

Ng TB, Wang HX (2004) A homodimeric laccase with unique characteristics from the yellow mushroom Cantharellus cibarius. Biochem Biophys Res Commun 313: 37-41.

Palmieri G, Bianco C, Cennamo G, Giardina P, Marino G, Monti M, Sannia G (2001) Purification, characterization, and functional role of a novel extracellular protease from Pleurotus ostreatus. Appl Environ Microbiol 67: 2754-2759.

Palmieri G, Giardina P, Marzullo L, Desiderio B, Nitti G, Cannio R, Sannia G (1993) Stability and activity of a phenol oxidase from the ligninolytic fungus Pleurotus ostreatus. Appl Microbiol Biotechnol 39: 632-636.

Perry CR, Smith M, Britnell CH, Wood DA, Thurston CF (1993) Identification of two laccase genes in the cultivated mushroom Agaricus bisporus. J Gen Microbiol 139: 1209-1218.

Saloheimo M, Niku-Paavola ML, Knowles JK (1991) Isolation and structural analysis of the laccase gene from the lignin-degrading fungus Phlebia radiata. I Gen Microbiol 137: 1537-1544.

She QB, Ng TB, Liu WK (1998) A novel lectin with potent immunomodulatory activity isolated from both fruiting bodies and cultured mycelia of the edible mushroom Volvariella volvacea. Biochem Biophys Res Commun 247: 106-111.

Shin KS, Lee YJ (2000) Purification and characterization of a new member of the laccase family from the white-rot basidiomycete Coriolus birsutus. Arch Biochem Biophys 384: 109-115.

Urbanelli S, Della Rosa V, Punelli F, Porretta D, Reverberi M, Fabbri AA, Fanelli C (2007) DNA-fingerprinting (AFLP and RFLP) for genotypic identification in species of the Pleurotus eryngii complex. Appl Microbiol Biotechnol 74: 592-600.

Wang HX, Liu WK, Ng TB, Ooi VEC, Chang ST (1996) The immunomodulatory and antitumor activities of lectins from the mushroom Tricholoma mongolicum. Immunopharmacology 31: 205-211.
Wang HX, Ng TB, Ooi VEC (1998) Lectin activity in fruiting bodies of the edible mushroom Tricholoma mongolicum. Biochem Mol Biol Int 44: 135-141.

Wang HX, Ng TB (2000) Isolation of a novel ubiquitin-like protein from Pleurotus ostreatus mushroom with anti-human immunodeficiency virus, translation-inhibitory, and ribonuclease activities. Biochem Biophys Res Commun 276: 587-593.

Wang HX, Ng TB (2001) Studies on the anti-mitogenic, anti-phage and hypotensive effects of several ribosome inactivating proteins. Comp Biochem Phys C 128: 359-366.

Wang H, Ng TB (2004a) A new laccase from dried fruiting bodies of the monkey head mushroom Hericium erinaceum. Biochem Biophys Res Commun 322: 17-21.

Wang HX, Ng TB (2004b) A novel laccase with fair thermostability from the edible wild mushroom (Albatrella dispansus). Biochem Biophys Res Commun 319: 381-385.

Wang HX, Ng TB (2004c) Purification of a novel low-molecular-mass laccase with HIV-1 reverse transcriptase inhibitory activity from the mushroom Tricholoma giganteum. Biochem Biophys Res Commun 315: 450-454.

Wang HX, Ng TB, Chiu SW (2004) A distinctive ribonuclease from fresh fruiting bodies of the medicinal mushroom Ganoderma lucidum. Biochem Biophys Res Commun 314: 519-522.

Wang HX, Ng TB (2006a) A laccase from the medicinal mushroom Ganoderma lucidum. Appl Microbiol Biotechnol 72: 508-513.

Wang HX, Ng TB. (2006b) Purification of a laccase from fruiting bodies of the mushroom Pleurotus eryngii. Appl Microbiol Biotechnol 69: $521-525$.

Widsten P, Kandelbauer A. (2008) Laccase applications in the forest products industry: A review. Enzyme Microb Tech 42: 293-307.

Zhang GQ, Tian T, Liu YP, Wang HX, Chen QJ (2011) A laccase with anti-proliferative activity against tumor cells from a white root fungus Abortiporus biennis. Process Biochem 46: 2336-2340.

Zhang JX, Huang CY, Ng TB, Wang HX (2006) Genetic polymorphism of ferula mushroom growing on Ferula sinkiangensis. Appl Microbiol Biotechnol 71: 304-309.

Zhao JK, Wang HX, Ng TB (2009) Purification and characterization of a novel lectin from the toxic wild mushroom Inoybe umbrinella. Toxicon 53: 360-366. 